\title{
Conexões entre a constituição da memória individual e os vestígios autobiográficos na prosa de Augusto Frederico Schmidt
}

Paulo Caldas Neto ${ }^{1}$

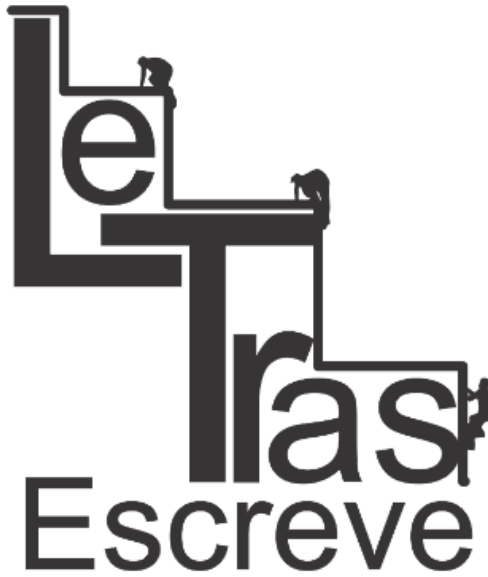

(ISSN 2238-8060)

Resumo: Estudar um escritor de nossa literatura sem muitas fontes bibliográficas, especialmente a sua prosa memorialística, não é tarefa fácil. A proposta aqui concentra seus argumentos em uma finalidade: a interrelação existente entre os aspectos da memória do narrador dos livros $A s$ florestas e O Galo Branco, exemplos de livros de recordações, em que o autor se confunde com um narrador que parece ter vivido integralmente o que narra, e outros gêneros (a biografia, a autobiografia, o diário etc.). Uma diferença entre eles é necessária, como também a construção desse discurso memorialístico do eu enunciador do texto e a do discurso histórico. Até que ponto se tem uma prosa voltada à problematização da própria arte e do narrador e uma prosa que visa mostrar uma outra face de um tempo histórico já bastante debatido nos documentos ou nos estudos da área da Ciência Histórica. É a partir disso que entra em ação a Historiografia enquanto método analítico, o qual nos faz repensar a História e de que forma a Literatura se utilizou desta para seus objetivos. Augusto Frederico Schmidt é autor da geração de 20 e 30 da História da Literatura Brasileira que talvez possa nos dar as respostas.

Palavras-chave: memória, autobiografia, narrador, historiografia.

Abstract: To study a writer of our literature without many bibliographical origins, specially his memoirs prose, it is not easy task. Here, the proposition concentrates its arguments in a finality: the interrelation existing between the aspects of the memory of the narrator of the books As florestas and $O$ Galo Branco, examples of memory books, in which the author is confused with a narrator who seems to have lived fully what tells, and others genres (the biography, the autobiography, daily etc.). A difference between them is required, as well as the construction of this memorialistic speech I enunciator text and the construction historic speech. The extent to which a face has been a prose for the questioning of art itself and of the narrator and a prose which aimed to show another face of a historical time already quite debated in the documents or in the studies of the area of Historical Science. Is from this that kicks in the historiography while analytical method, which makes us rethink the History and how the Literature was used of this to your goals. Augusto Frederico Schmidt is author of the generation of 20 and 30 in the History of Brazilian Literature that might give us the answers.

Keywords: memory, autobiography, narrator, historiography.

${ }^{1}$ É graduado em Letras-Licenciatura plena em Língua Portuguesa e LiteraturasUniversidade Federal do Rio Grande do Norte. Mestre em Estudos da LinguagemLiteratura Comparada (UFRN). Professor- Classe D303 do Instituto Federal de Educação, Ciência e Tecnologia do Rio Grande do Norte. E-mail institucional: paulo.neto@ifrn.edu.br.

https://periodicos.unifap.br/index.php/letras

Macapá, v. 6, n. I, Io semestre, 2016. 


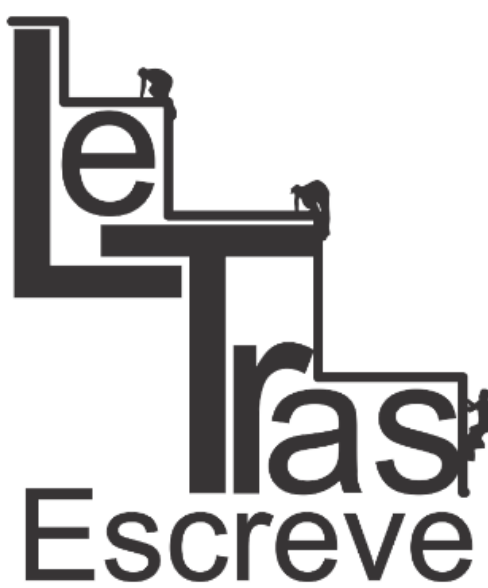

(ISSN 2238-8060)

Um estudo perspicaz demonstrou que a relação que Augusto Frederico Schmidt tem com a literatura, especialmente a poesia, é profética. O que leva a crer que quem se atreve a ler sua obra, seja em versos, seja em prosa, depara-se com uma busca constante por respostas que, muitas vezes, a própria literatura não dá. Sua prosa de memórias, mais discursiva como toda prosa, parece desenvolver certas explicações que o poema só pode sugerir, consolando um pouco a angústia existencial do autor.

Percorrendo as páginas de $\mathbf{O}$ Galo Branco e As florestas, seus mais conhecidos livros memorialísticos, confere-se a narrativa em prosa que abre espaço à retórica e ao estilo derramado do poema, mas com um maior destaque para a meditação. Este elemento trabalhará, evidentemente, a consistência da memória enquanto força-motriz do discurso literário, que também dará origem a uma investigação de seu elo com o discurso histórico, já que o homem é quem constrói a sua própria história e a de seus semelhantes. Uma torrente de recordações invade o narrador schmidtiano a ponto de termos um relato de um autor cujo passado não o deixa seguir adiante; está a cada texto mais vivo e agitador. É como se fragmentos do seu ego ajudassem a escrever aquela que seria a sua história, enquanto escritor, homem de negócios e articulador político, na autêntica história da humanidade; e aí se tornam perceptíveis as circunscrições ideológicas do existencialismo e da procura por respostas aos males do ser pela via do etéreo.

Acontecimentos passados marcaram a vida do autor carioca e ex-caixeiro viajante que talvez venham a justificar sua obsessão pela temática da metafísica religiosa como fonte de elucidações para o fantasma da morte, que tanto esteve presente em sua biografia. Lembranças de momentos íntimos em família, com os amigos e supostas namoradas vão surgindo gradativamente em seus relatos narrativos de cunho autobiográfico na condição de meras confissões, oferecendo, ao mesmo tempo, a sobrevivência, a resistência, registro do tempo, vontade de escrever e conservação 


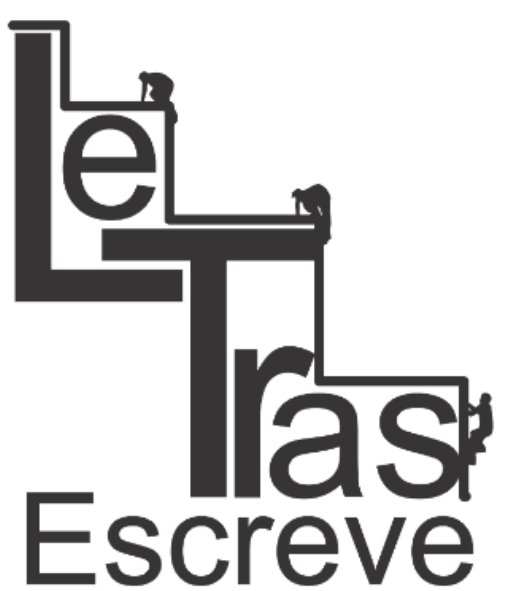

(ISSN 2238-8060) da memória. Tudo isso nos leva a pensar em uma escrita autobiográfica em forma de diário, mesmo que alguns dos textos prosaicos possam, às vezes, lembrar crônicas jornalísticas.

O fato é que uma análise circunstancial da realidade se dá de maneira diária. Em sua biografia, também há informações de que Schmidt costumava escrever seus poemas, artigos e demais textos sempre na hora noturna após um dia intenso de trabalho empresarial e político, uma vez que teve uma grande participação articulista durante a Era JK. Muitos de seus escritos lembram diários, um gênero textual pouco cultivado em nossa literatura, no entanto, com um significado expressivo bem particular, porque mostrava a tentativa de um eu-narrador em encontrar sentidos que esclarecessem a função do seu eu no mundo. O caráter meditativo de sua prosa aponta caminhos para uma reflexão crítica sobre a importância do diário enquanto gênero adotado. Parece que Schmidt procura um refúgio em sua prosa de memórias a fim de comprovar a cumplicidade que esta lhe garante na elucidação de certos temas universais; um deles, a morte. Entender tal fenômeno ajuda a lembrar de cenas vividas ao lado daqueles a quem tanto amou. Uma figura exemplar que o autor de Pássaro cego sempre retoma como um ente querido, que para ele foi a representação do amor sublime e da fidelidade, é a tia Tetéia, alcunha íntima de Filomena Abrilina, irmã de sua avó. Por isso, com ar confessional, o texto A morte escolhida, de As florestas, traz uma meditação acerca do fim da existência, extraindo uma nova ideologia:

O medo da morte é menor hoje em mim do que outrora. Mas, ainda assim, lamento o destino do homem que sabe que vai morrer. Toda sua superioridade está nisso, nessa consciência, é certo, mas o próprio conhecimento de que somos transitórios, efêmeros, não deixam de conflituar dolorosamente com as raízes que nos prendem ao reino terrestre e a algumas criaturas que amamos e sabemos que estão provisoriamente ao nosso lado. O ser com que trocamos confidências mais íntimas deixará amanhã de existir, transformar-se-á em alguma coisa de estranho a nós, de muito longínquo. (SCHMIDT, 1997, p. 255) 
A reescritura do passado pelo narrador é o resgate de muitas dúvidas ainda a deixarem-no seguro de pelo menos uma coisa: morrer é o fim. Não existe nesse sentido uma visão espiritual, concedendo uma defesa de que a vida se prolonga no além-túmulo. Para o escritor carioca, a morte é a imobilidade de tudo e nada mais. A analogia com o sono sintetiza tal ideia. Isso se confirma no último parágrafo quando retoma a imagem da tia, próxima do estado de letargia:

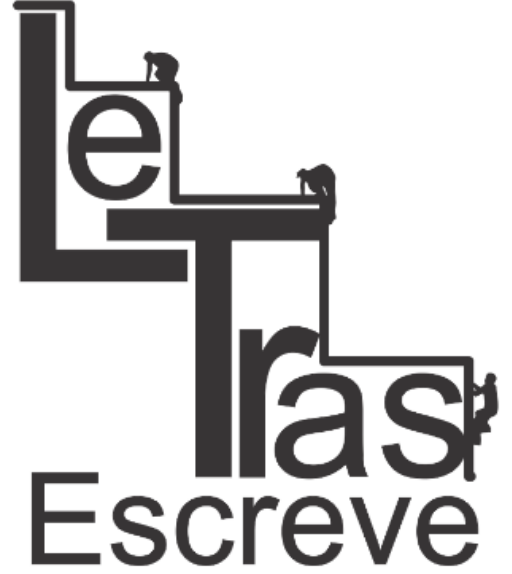

(ISSN 2238-8060)
Revejo-a assim, na porta de seu quarto de dormir, contente porque não teria a morte que mais temia [em vez de morrer de câncer conforme o narrador do texto menciona, a personagem morreria de pleurisia]. O que lhe causava alegria, seria uma razão de chorar. Somos todos uns pobres seres, uma infeliz família de perseguidos que se perseguem, de eternos devorados que se entredevoram. O que nos enaltece, o que nos eleva, o que nos dignifica é apenas o sabermos que seremos algum dia, mais cedo ou mais tarde, arrancados do mundo em que vivemos. (SCHMIDT, 1997, p. 256)

O lado diarista tem como finalidade que certas reflexões e pensamentos sejam lembrados no futuro pelos leitores, como se fosse intenção de Augusto deixar indícios de sua passagem pelo mundo, e as gerações seguintes não o esquecessem, bem como a sua própria história, por mais curta que possa aparentar ser. Assim, procura manter o diário vivo, completo. E é nessa atividade discreta, em local íntimo, na maioria das vezes irregular, que se desenvolve o empenho por torná-la séria e regular; por isso, alguns dos relatos dos dois livros memorialísticos aqui citados, ganham uma dimensão de narrativas longas, pois o ar de brevidade pode suprimir ou até mesmo inutilizar fatos da vida de seu autor, aqui encarado também qual sujeito histórico. Outro detalhe é que o diário manifesta a apreensão com o tempo, o que está claro na prosa schmidtiana, detentora de um estilo e modelo próprio com relação ao gênero discursivo em questão, uma vez que este trilha caminhos variados. Daí, as mais variadas personalidades de diaristas e não-diaristas por acaso. De certa forma, há aí uma função social: é mais frequente a

https://periodicos.unifap.br/index.php/letras Macapá, v. 6, n. I, Io semestre, 2016. 


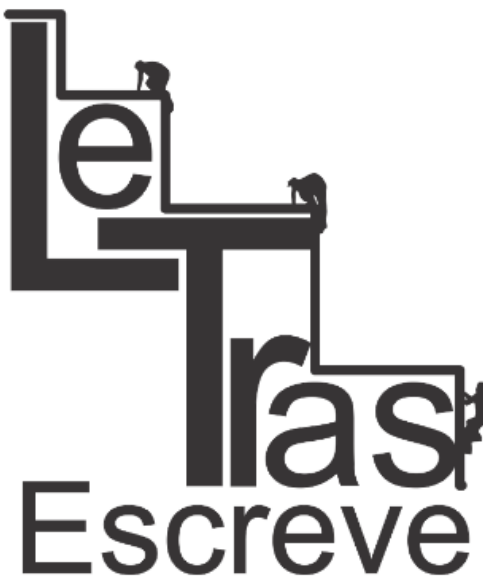

(ISSN 2238-8060) prática de escrever diários entre as pessoas instruídas e urbanas. Como se trata de um gênero que quase ninguém lê e, muitas vezes, é visto qual uma escrita sem sentido, porque geralmente não visa à publicação, poderíamos assistir, talvez, a uma futura despersonalização da vida social; ou, simplesmente, se formos bastante maduros, uma progressiva individualização do controle da vida, que gere o curso do tempo. Há que se possa encarar também o diário enquanto delegação do poder, isto é, os indivíduos teriam o mister de administrarem as próprias experiências em seus arquivos particulares.

Schmidt perpassa esse objetivo quando registra acontecimentos da infância, do cotidiano, do trabalho, da intimidade, numa procura por esclarecimentos de suas ações e das ações da humanidade. Isso é possível porque, sob a forma de diário, seus textos memorialísticos e autobiográficos compreendem uma série de vestígios datados. A autoanálise a respeito de fatos históricos, ligados à biografia do autor, ajuda a compor o discurso literário e, ademais, o discurso histórico, quase em tom de profecia. É o que se observa no narrador de $\mathbf{O}$ filho do século, narrativa real que integra as páginas de $\mathbf{O}$ Galo Branco. Nela, existe um relato crítico sobre a situação do autor-narrador, ainda criança, na Suíça, em Lausanne precisamente, para onde a família se mudara nos primeiros anos do século $\mathrm{XX}$, com o fito de achar paragens arejadas como cura para a doença da mãe do poeta. Por essa época, aproximavam-se os rumores da Primeira Grande Guerra em toda a Europa. Se não, vejamos:

Este século tinha seis anos quando nasci. Era esse o tempo da segurança, dos direitos adquiridos, o tempo em que tudo se regia pelo princípio da inviolabilidade do ser humano. Depois, veio 1914. Muito criança ainda, lembro-me, porém, desse ano terrível e das suas repercussões próximas, das repercussões da guerra sobre a minha infância. É que, ainda menino, encontrava-me na Europa, vizinho dos acontecimentos. Num internato na Suíça, nessa inesquecível Lausanne, que mais tarde comovidamente visitei, homem maduro, ressoavam os

https://periodicos.unifap.br/index.php/letras

Macapá, v. 6, n. I, Io semestre, 2016. 
ecos da tragédia que bem perto se desenrolava. (SCHMIDT, 2006, p. 149)

Está óbvio que o documento em prosa data, como referência, o período do primeiro Entre guerras que abalou o mundo com o seu alto poderio militar, dando sinais de que seria apenas o início de tudo. O texto comove porque é a escrita do testemunho. Tais circunstâncias deixaram marcas no escritor e, de alguma maneira, tiveram um elo com a sua vida; do contrário, não nos depararíamos com um discurso extremamente particular e meditativo. Tem-se a prova de que o discurso histórico só significa algo quando possui um sujeito inserido, interpretando, atribuindo símbolos, sinais de que a realidade se compõe de muitas outras; o que de fato torna-se passível de questionamentos. $O$ bom do diário é que,

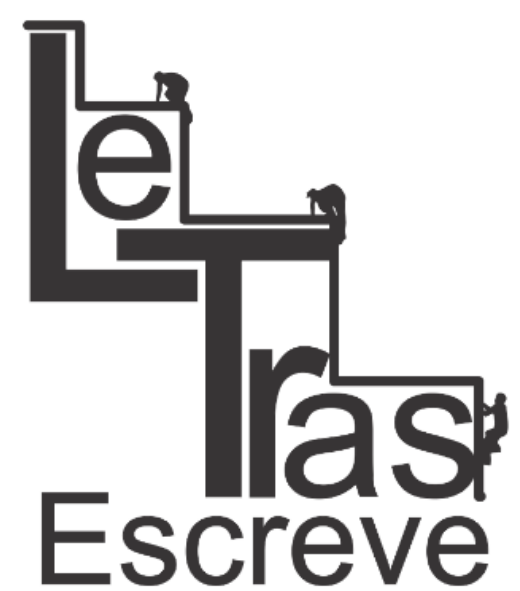

(ISSN 2238-8060) independentemente do tempo futuro, ele não pode ser alterado, sob pena de perder a autenticidade do instante. Porém, é interessante notar que, no caso da escrita schmidtiana, essa documentação do instante mantém a marca da subjetividade em função de seu liame com a autobiografia. Existem vestígios que têm o objetivo de balizar o tempo, apropriando-se de uma série de referências. Segundo Lejeune (1998), em seu ensaio O Pacto autobiográfico, nessa sequência de traços, um deles predominará e terá uma meta distinta no interior do relato diário: não acompanhar o transcorrer dos tempos, mas fixá-los em um momento-origem. Assim, sair-se-á do plano do diário e entrar-se-á no plano do memorial. Tal mescla de gêneros e de discursos parece presente na obra em prosa aqui em análise. Ao mesmo tempo em que Schmidt decide construir a sua memória, quer seduzir quem o lê, o que clarifica nosso estudo sobre o gênero, principalmente, no que diz respeito à sua estrutura: assim como no diário, os textos de memórias do referido autor são repletos de lirismo, narrativa, asserção, e o nível de linguagem empregado revela erudição e retórica a bel-prazer. A flexibilidade em seu corpus textual é livre. 
Interessante notar que, ao se escrever primeiramente para si mesmo, acaba-se sendo o destinatário do futuro. Registram-se os elementos do passado, relacionando-os à memória, de modo que ninguém conseguirá ler o diário da mesma forma que o autor leria. Isso mostra que há sempre um rastro em todo o texto prosaico, deixado por quem o escreve, com o objetivo de recontar os eventos e reorganizá-los a ponto de conferir-lhes uma identidade narrativa. Augusto Frederico Schmidt tem essa fixação e sente-se sujeito de um momento social e histórico. Ainda em $\mathbf{O}$ filho do século, percebe-se tal empreendimento:

Todas essas imagens retornam com o meio século, com o lançar da âncora no porto do último ano cinquentenário. A história do nosso tempo é sempre a nossa própria história. $\mathrm{E}$ a história, para mim, deste meio século, sou eu mesmo, o que vi, o que senti. $O$ melhor testemunho [da História] é o homem que fielmente se lembra da sua vida", escreveu o poeta Péguy. (SCHMIDT, 2006, p.150)

Nesse pensamento de continuidade, Schmidt vai se protegendo do esquecimento e da morte. Cria uma expectativa num horizonte em que o que documenta se reduplica, assumindo valor de eternidade. Vai escrevendo e reescrevendo, e essa alternativa the dá segurança quanto à sobreposição de sua obra ao que seria considerado o fim de tudo. O fio do tempo chega, dessa forma, ao infinito. É o diário se configurando em um instrumento de resistência à ação corrosiva dos tempos, uma vez que ensaia rituais de encerramento, que se sabe, na verdade, serem um encerramento parcial, levando o leitor a crer numa espécie de etapa, com uma atenção voltada para o passado, outra para o futuro. Mas sempre, se se observar, essa maneira de enxergar a escrita diarista produz uma corrente: chega-se ao fim para se determinar o fechamento de um ciclo. Isto é: faz-se necessário se repensar o que se escreveu para se poder seguir para a próxima página ou o próximo caderno. Realizando-se um balanço do que foi arquivado, é que se consegue 
evitar parar o registro, ou melhor, o fim. Chama-se esse fato de fim do suporte:

O encerramento pode intervir em fim do período (semana, mês, ano...) e comportar um resumo (informação) e/ou um balanço (apreciação) daquele período que se conclui. Essa atividade é muitas vezes programada pelo suporte: um espaço suplementar deixado ao fim de cada ciclo. (LEJEUNE, 1998, p. 277)

O planejamento desse suporte e a escolha dele é que livram o escritor da angústia da morte. A indefinição do tamanho do caderno que comporta o relato pode obrigá-lo, de uma forma ou de outra, a parar de escrever, mas também é possível a procrastinação do encerramento. O curioso é que essa relação do tempo por meio do espaço cessa a partir do momento em que a narrativa cotidiana

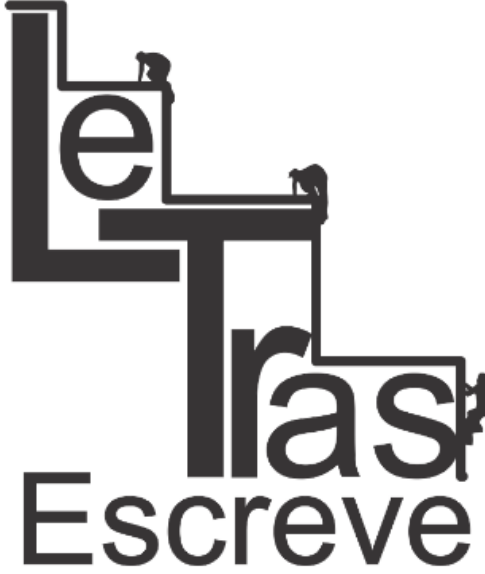

(ISSN 2238-8060) adota como base o livro. Quando Augusto Frederico Schmidt nos conta o seu presente, e este oscila com o passado, tem a consciência de que os seus registros particulares, após a impressão em jornais e, sobretudo em um volume, exprimem mais um povir indeterminado e limitado pela morte que necessariamente a mera anotação de eventos atuais e sucessivos. Quiçá a técnica do lance ao amanhã e o retrocesso ao tempo do narrador se expliquem, porque a escrita não é um fim, mas a transcendência para que se efetuem releituras futuras. Em referência ao texto schmidtiano, até o momento examinado, a constatação de que o narrador reflete sua condição humana, como também a da sociedade de sua época, manchada pelos horrores da guerra, avigora o porquê de se evitar o desfecho da história: o constante questionamento de si mesmo e do papel dos semelhantes, também inclusos nesse processo sociopolítico:

Sou nascido com a Primeira Guerra; os meus mitos, os meus brinquedos, os primeiros momentos do despertar da minha inteligência, por ela foram tocados, por ela cresceram envolvidos. [...] Essa primeira guerra do século escondia a outra guerra, a que, dentro de vinte anos, mergulharia 


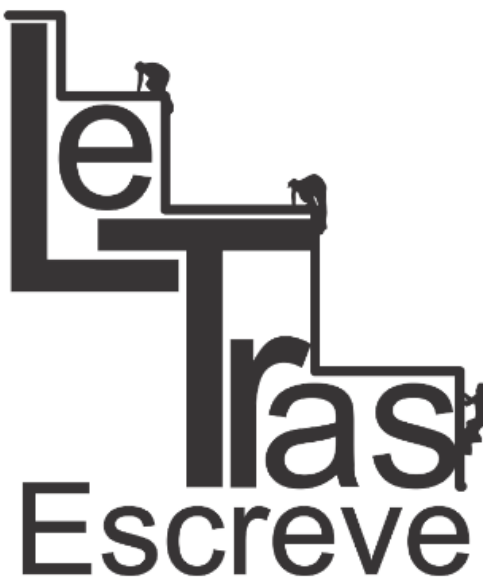

(ISSN 2238-8060) novamente 0 ser humano em um horror, desta vez inimaginável. [...] Chegamos agora ao ano cinquenta, surpreendidos com a sobrevivência deste mundo e certos de que estamos ameaçados, mais ameaçados ainda. (SCHMIDT, 2006, p. 151-152)

Desperta indiscrição a autoafirmação do narrador em evidenciar que é o autor da história, levando-nos a estudar o elo entre a autobiografia, presente no relato schmidtiano, e o diário. A diferença entre ambos os gêneros reside no fato de aquela ser uma escrita terminável, enquanto esta é interminável. Entretanto, o diário, funcionando qual autobiografia, pode ter um fecho, assim como a autobiografia, na condição de diário, assume o seu papel de continuidade. Na obra enfocada, especialmente nesse último texto, testemunha-se o intuito em reconhecer-se um tempo posterior à escrita, exigindo uma nova escrita que, cedo ou tarde, irá de encontro à morte. É graças a esse liame que se tem essa mobilidade da narrativa de Augusto Frederico Schmidt em projetar seu alcance no futuro e incorporá-lo às construções do passado. O lance de verter o diário temporariamente em autobiografia garante o instituto de diário, passível de prósperas reinterpretações; trabalha o movimento de representação do tempo da escrita, que confere ao texto a dimensão de um futuro inacabado até que o fechamento da autobiografia esteja decidido. É construída, nessa narrativa de eventos reais, a atitude de complementar os efeitos ou vestígios de um gênero com o auxílio do outro, montando uma relação de hierarquização ou de dominância. Schmidt demonstra esse aspecto em sua obra, revelando também o desabafo de um eu que quer descarregar o peso de suas frustrações para com a existência e o que ainda lhe espera. As noções de conservar e destruir, por meio do ato de escrever, levam esse eu à purificação frente às experiências remotas que o atormentam.

Liberado do encosto de permanecer sustentando as barras do passado pela purgação, através da escrita, o eu, a partir daí, sentese aliviado e consegue seguir o curso da vida. A função de

https://periodicos.unifap.br/index.php/letras Macapá, v. 6, n. I, Io semestre, 2016. 


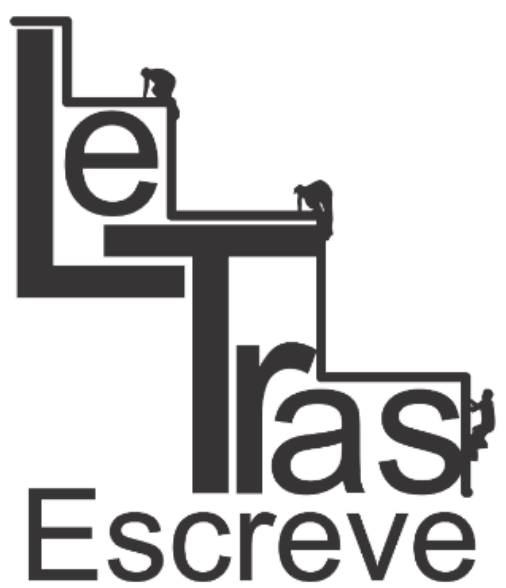

(ISSN 2238-8060)

expressão, no ato de escrever, dissocia-se da função da memória, que é meramente a de documentar, para assumir a função de esquecimento. Nesse ritual, o autor de $\mathbf{O}$ Galo Branco liberta-se por alguns instantes do peso de certas experiências, mesmo sabendo que elas precisam ser preservadas como as suas pequenas histórias, pois as gerações futuras terão que ter esse contato com o que já passou, para poderem avaliar o presente e o futuro. Em cada gesto, momento ou palavra, usados pelo autor, há a tentativa de decifrar a ação dos anos, tomando, algumas vezes, qual ponto de referência, ocasiões com os entes queridos, que, para si mesmo, representaram o aprendizado de valores sociais e universais; dentre estes, a dificuldade do homem em lidar com o transitório. No texto, $\mathbf{O}$ retrato, de $\mathbf{O}$ Galo Branco, suas páginas de memórias, presente na antologia Saudades de mim mesmo, contempla-se esse raciocínio quando Schmidt discute o sentido das lembranças que lhe surgem de sua avó Chiquinha a partir de uma fotografia antiga encontrada:

[...] Um retrato assim nos traz à consciência a noção da fuga das horas, e a confirmação de que nada resiste ao tempo; nada resiste, nem as grandes obras do poder do homem, nem o sorriso meio triste das meninas que parecem pressentir, pela verde melancolia que revelam, o que há de duro, de cruel na existência; o que há de áspero em todos os destinos, mesmo nos que não são particularmente terríveis. (SCHMIDT, 2006, p. 174)

Domar o tempo, construindo uma memória de papel e, no interior desta, arquivos como sinais do que se viveu, é reunir vestígios e maquinar o esquecimento, aplicando à vida mais consistência e continuidade. A missão do memorialista é essa. No caso de Schmidt, um destino. Praticamente a busca da fixação temporal se faz constantemente pela reinserção das informações novas de um texto diarista e também memorialístico no fluxo da existência. Isso ocorre porque o autor consegue fazer com que os escritos diários não tenham como função o mero registro que logo se entregará à morte, ao olvido; antes procura mantê-los com

https://periodicos.unifap.br/index.php/letras Macapá, v. 6, n. I, Io semestre, 2016. 


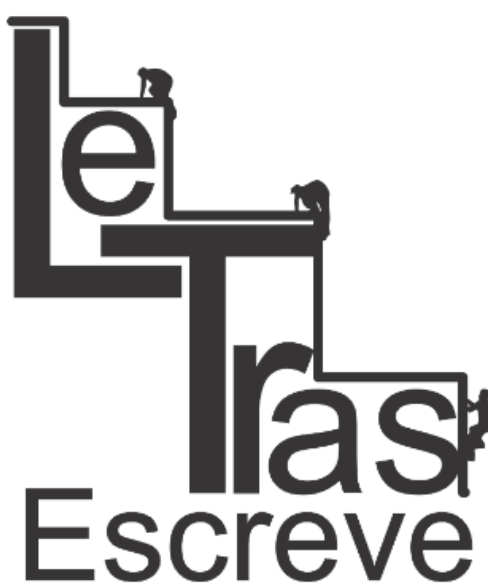

(ISSN 2238-8060)

convicção pelos processos de interrupção e retomada, incrementando em sua estrutura textual experiências, das quais uma específica se destaca. Por conseguinte, é que se tem um gênero como a memorialística, versando sobre variados episódios já remotos. Além disso, conservar um registro como esse, detentor de uma escrita ameaçada pela ação do tempo, é um ato de coragem e persistência, pois o autor dela perecerá, mas ela não.

Semelhante explanação da narrativa schmidtiana, ora com aspectos de um diário, ora com aspectos de um texto de memórias, acaba demonstrando a presença de um pacto em seu interior, certo de que elementos autobiográficos se misturam a um simples relato de situações acontecidas. À proporção que o autor fluminense vai narrando eventos pessoais e coletivos, encontrando relações entre eles, torna-se perceptível o escopo de se dar ênfase a um sujeito que não quer ser esquecido pelos compatriotas de sua época, nem pelos que comporão as gerações seguintes. É um sujeito que faz de suas experiências particulares experiências universais, ensinandonos que nós é quem fazemos nosso tempo. Há identificação clara tanto nas narrativas de seus dois livros de prosa, citados anteriormente, entre as figuras do autor e do narrador, ambos preocupados na edificação de retrospectiva histórica. O que não significa dizer que quando se pesquisa autobiografia deve-se achar que sempre será um texto memorialístico. Nem sempre. E aí entramos na questão do gênero.

Classificar relatos schmidtianos em autobiográficos, puramente, seria um risco, uma vez que o relato memorialístico litiga com a retrospectiva de ações, como o fariam o diário, antes analisado, o autorretrato, dentre outros. Ocorre uma combinação de todos eles, e esse artifício torna instigante e original a estética que ajuda na composição da obra. Lapsos da vida individual do autor são encontrados nos textos, mesmo quando a primeira intenção é a transcrição de fatos; o que, entretanto, não constitui uma autobiografia em si. Por outro lado, é possível o exame desses 
toques entre estes gêneros: o autobiográfico e a memória. Reforçando o argumento, têm-se:

É óbvio que essas categorias não são absolutamente rigorosas: certas condições podem não ser preenchidas totalmente. O texto deve ser principalmente uma narrativa, mas sabe-se a importância do discurso na narração autobiográfica; a perspectiva, principalmente retrospectiva: isto não exclui nem seções de auto-retrato, nem diário da obra ou do presente contemporâneo da redação, nem construções temporais muito complexas; o assunto deve ser principalmente a vida individual, a gênese da personalidade: mas a crônica e a história social ou política podem também ocupar um certo espaço. Trata-se de uma questão de proporção ou, antes, de hierarquia: estabelecem-se naturalmente transcrições com os outros gêneros da literatura íntima (memórias, diário, ensaio) e uma certa latitude é dada ao classificador no exame de casos particulares. (LEJEUNE, 1998, p. 15)

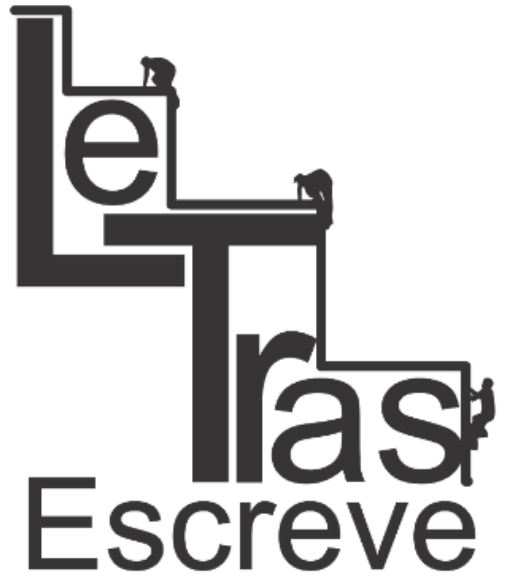

(ISSN 2238-8060)

Em Augusto Frederico Schmidt, boa parte dos textos prosaicos de As florestas, por exemplo, manifesta identidade entre os seguintes elementos da narrativa e que causam polêmicas quanto à diferenciação dos gêneros antes citados: autor-narradorpersonagem. Mas é bom ter cuidado porque não será sempre que se terá essa corrente, pois, em outros relatos, o narrador-autor limita-se ao puro apontamento das circunstâncias históricas e sociais. Quando acontece de usar o narrador em $1^{\text {a }}$ pessoa, é notória a procura da identidade entre este e o autor, como se Schmidt quisesse, em todos os passos de sua história individual, torná-la também coletiva, resgatando experiências e vivências do passado (algumas muito específicas) para que os componentes autobiográficos se imiscuam em meio aos coletivos. De certa forma, acaba nos levando a questionar e a conhecer informações que nos direcionam a repensar a História da Humanidade. Tudo isso se deve ao pacto que o autor, o narrador e o personagem do texto fazem entre si, o que acende a discussão sobre até onde se tem uma narrativa autobiográfica ou não. A confusão que sempre se faz para se definir os gêneros é ocasionada por problemas de natureza gramatical com os problemas da identidade discursiva. Empregam- 


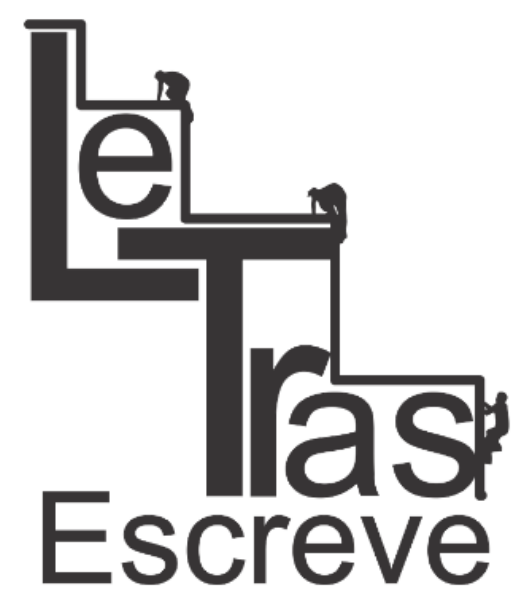

(ISSN 2238-8060) se em um texto, para se referir a $1^{a}, 2^{a}$ e $3^{a}$ pessoas, pronomes como EU, TU e ELE, que distinguem as pessoas do discurso na enunciação. Sabe-se que o primeiro pronome citado faz referência ao falante; e os outros, àqueles que ouvem e àqueles sobre os quais se fala. O que se pretende mostrar é como se dá a identidade do autor e narrador no discurso schmidtiano, partindo dessa concepção linguística e enunciativa da linguagem.

Se o enfoque fosse de um discurso oral, a princípio, poder-seia dizer que o eu do enunciado estar-se-ia referindo-se àquele que fala, conforme se explicou, sem nenhuma dificuldade de identificação. Da mesma maneira, seria fácil identificar-se o interlocutor ou o ouvinte; todavia, se se tratasse de uma citação (o discurso dentro do discurso) ou de um discurso oral à distância (conversas por telefone, no escuro ou atrás de uma porta), provavelmente se teriam problemáticas no que diz respeito à identificação desses sujeitos discursivos. Como a análise em foco visa investigar um gênero escrito, o problema é resolvido, porque, a menos que a pessoa deseje permanecer anônima, o enunciador do discurso deve permitir a própria identificação, sanando, assim, o enigma da identidade. No relato Lausanne, cidade da Suíça, onde Schmidt passou parte de sua infância com os pais e irmãs, é visível o intimismo com que o autor de As florestas menciona coisas, lugares, objetos, dentre eles, o colégio no qual estudou na primeira década do séc. $\mathrm{XX}$, o Champs-Soleil. Esse texto presente em As florestas - páginas de memórias, é um testemunho do que representou cada momento de paz, intimidade familiar, nos quais o sujeito enunciador e, pelo próprio pacto estabelecido com o que escreve, concilia o seu amor pelas lembranças e entes queridos com o verdadeiro caráter confessional que a literatura pode lhe proporcionar. Na narrativa, o eu-Schmidt coloca o leitor a par da existência desse acordo entre sujeito enunciador, autor e personagem principal. Exemplifique-se o dito por meio do extrato a seguir:

https://periodicos.unifap.br/index.php/letras Macapá, v. 6, n. I, Io semestre, 2016. 


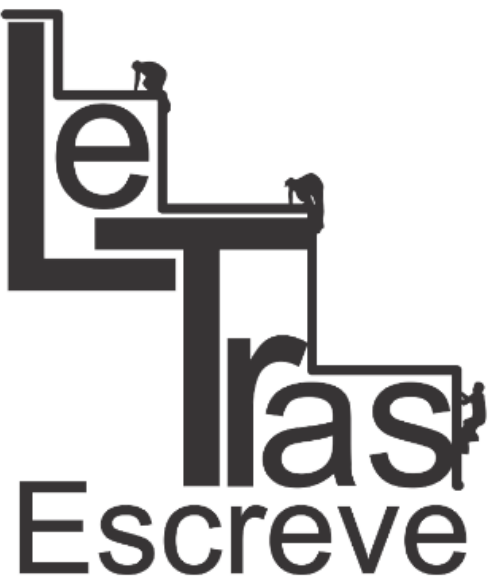

(ISSN 2238-8060)

Na memória, guardei alguns episódios passados bem em frente ao lago, em 1914, episódios a que dei minha interpretação, naturalmente inexata, de criança. Um deles é o encontro de dois homens ainda jovens, que se abraçaram efusivamente, enquanto um dizia ao outro: "Mas tu tinhas morrido! Como posso encontrar-te aqui? Deixa que eu te toque".

"É um caso de ressureição - dizia-me eu. - Um caso de ressureição que acabo de presenciar." - "Podemos encontrar então também nosso pai (que acabara de morrer em MontreuxTerrité, ao lado de Lausanne), assim de uma hora para outra", confidenciei a minhas irmãs, que de nada pareciam entender...

[...]

Lembro-me também de que, estando minha avó conosco, à beira do lago, numa tarde, já em 1915, se não me engano, e ouvindo uma família falar português dirigiu-se prontamente ao grupo e perguntou se um dos seus componentes não era Mário D'Artagão, poeta e banqueiro, de raízes sul-rio-grandenses, mas integrado na vida lisboeta. (SCHMIDT, 1997, p. 28-30)

Deixando implícita a intenção autobiográfica ao identificar-se com as eventualidades narradas, ao longo dessa pequena história, vai averiguar-se o reencontro do escritor com as suas raízes pelo fio da memória, profetizando os fins dos novos tempos. O controle sobre os próprios pensamentos e lembranças aparece quase como uma obsessão, uma busca de explicações para a sua própria pessoa. Acontece que as lembranças são remotas, da infância, e o eu só as recupera por fragmentos. São cenas esparsas que mais parecem deixar dúvidas do que necessariamente aclarar a mente do autor, outra vez em contato com esse mundo tão novo e diferente dos seus olhos da meninice. Se não, vejamos:

Em Lausanne, havia uma espécie de areal, aonde fomos, certa vez, ver um avião primitivo, que lá pousara. E vinham à cidade, às vezes, circos grandiosos e havia festas públicas, com feiras, exibições, vendedores de doces em barracas. $E$ havia muitos mistérios, que só se dissiparam depois de muito tempo.

Agora, neste outono de 1952, passeio sozinho, enquanto fumo o meu charuto antes de dormir. Passei o dia procurando o reino da infância. Visitei o Champs-Soleil, que já não é mais nada do que foi, transformado numa espécie de asilo de moças. Andei procurando a casa em que habitávamos com o casal Abrahms, nossos preceptores. Havia em frente a essa casa um hotel, cujo nome julgo ter sido Royal Hotel, importante porque possuía um campo de tênis.[...]

Lausanne, Leysin, a Suíça enfim, tudo era grande para os meus olhos infantis. (SCHMIDT, 1997, p.30-31)

https://periodicos.unifap.br/index.php/letras

Macapá, v. 6, n. I, Io semestre, 2016. 


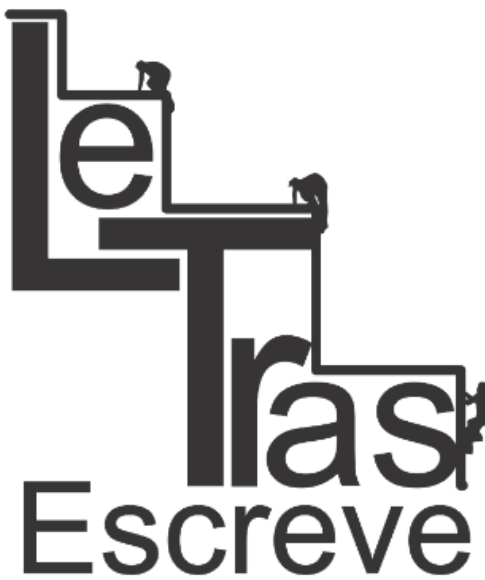

(ISSN 2238-8060)

Nome próprio e pessoa do discurso se proferem até, em seguida, se proferirem na primeira pessoa. Isso acontece muito no discurso oral quando se está experimentando a aquisição da linguagem. Faz-se muita menção a um nome próprio, designando um alguém; depois, fica mais simples e óbvio aplicar o pronome eu para falar de si, sabendo que este sempre remeterá a um nome específico no interior do enunciado. Para aquele que for aventurarse na leitura de $\mathbf{O}$ Galo Branco e de As florestas, descobrirá essa cena, em que o enunciador aparece sob a representação de um eu, porém, espontaneamente associará as ações e eventos presenciados por essa pessoa discursiva ao sujeito Augusto Frederico Schmidt, de carne e osso e cuja identidade é recuperada quando de sua enunciação no título da capa dos livros. É dessa exposição autoral e de sua relação com o sujeito enunciador presente no texto que surgem os problemas da autobiografia. Há uma pessoa real a quem se atribui todo o encargo do que está sendo informado no texto escrito, e, assim, essa marca da realidade extratextual desfaz parte da dúvida sobre a identidade entre o ser do discurso, feito de papel, e o ser real. Uma espécie de contrato é produzida, ratificando a credibilidade do conteúdo da enunciação.

O texto schmidtiano cumpre esse papel, levando quem o lê a perceber que as informações são verídicas, embora se possa pensar também em uma ficção. Questionamentos sobre a semelhança entre a realidade e a fantasia poderão aparecer, no entanto, nunca abordarão a identidade, já que o pacto autobiográfico se manifesta de várias formas, e todas elas transparecendo a intenção do autor em dignificar sua assinatura. É importante, ademais, prestar a atenção no tipo de contrato feito entre o autor e o leitor, muitas vezes, percebido pela própria atitude do leitor, que é motivada pela afirmação ou não afirmação da identidade daquele que escreve o relato. $O$ que se sabe é que a identidade de nome entre autor, narrador e personagem, no caso da prosa de Schmidt, se dá de 


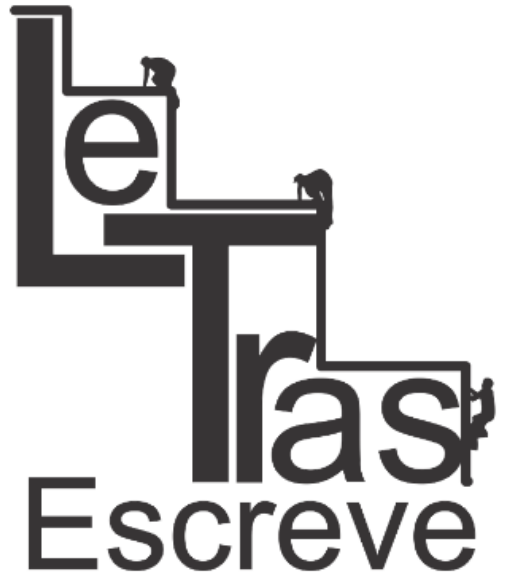

(ISSN 2238-8060) maneira implícita no momento do pacto, sobrevindo mais na forma de seção inicial do texto, no qual o narrador se compromete junto ao leitor a comportar-se como o autor, não restando incertezas quanto à relação do eu com o nome escrito na capa do livro. Todavia, esse nome não aparece repetidas vezes ao longo da narrativa. Em textos de As florestas, como A velha firma, o sujeito enunciador cita fatos de sua vida profissional, principalmente reflexões de experiências do seu primeiro ofício na condição de empregado em uma empresa de peças, confecções e armarinho:

Caminhando há poucos dias pela Rua da Quitanda, os meus olhos pousaram nos tempos idos, no meu passado. A representação desse passado era um tanto confusa e já desfigurada; tratava-se apenas de um prédio que reconstruíam, transformavam, modernizavam. Nesse prédio, situado no trecho compreendido entre a Rua do Ouvidor e a Sete de Setembro, estava outrora instalada a poderosa firma de fazendas e armarinho, que girava sob o nome de Costa, Pereira \& Cia.

[...]

Nesse prédio da Rua da Quitanda, agora em reparações, com andaimes e seu soalho arrancado, vivi eu mais de três longos anos de iniciação comercial. Ali trabalhei em diversas seções. Ajudei no terceiro andar à confecção de leques, que um japonês minúsculo e competente fabricava com extraordinária agilidade. Tentei, outrossim, ajeitar-me no departamento de amostras, dirigido pelo Senhor Coutinho. Depois passei largo tempo no segundo andar, onde se encontrava o depósito de tecidos e atoalhados. Só mais tarde é que fiquei no térreo, como auxiliar de arrumação. Vagaroso e melancólico, fazia puxadas. O que chamavam puxadas era a deslocação de mercadorias de um local para outro das prateleiras. (SCHMIDT, 1997, p. 66-67)

Já se atentou que o principal fito da escrita autobiográfica é aproximar-se do discurso real. A prosa de Augusto Frederico Schmidt, mero relato de memórias, trabalha a semelhança de um subgênero a outro sob dois níveis: o da exatidão e da fidelidade. Levando em conta os elementos que permeiam a narrativa memorialística com traços autobiográficos, as informações que o texto fornece aguçam a impressão do leitor de que há veracidade nelas; o narrador-autor (e mais uma vez reforçamos) apresenta um

https://periodicos.unifap.br/index.php/letras

Macapá, v. 6, n. I, Io semestre, 2016. 


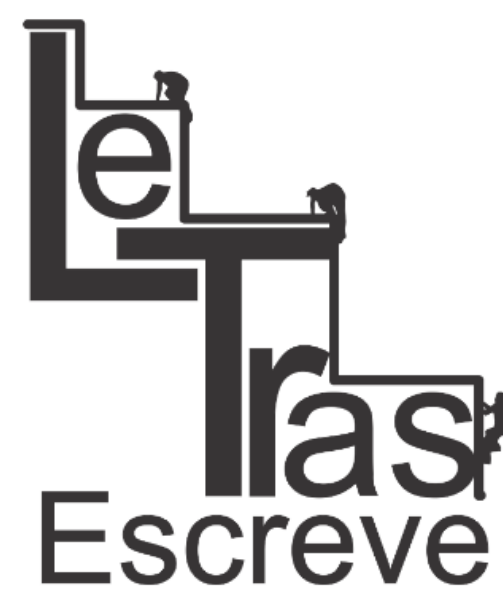

(ISSN 2238-8060) indício de querer uma proximidade com o fato coletivo, tornando sua própria experiência como coletiva, a saber, universal. Por isso, a interferência desse critério da exatidão. Quando retrata as suas impressões sobre essas vivências, deseja extrair-Ihes significados, até mesmo para a sua existência. A eternização do que se afirma é mais um forte testemunho a ser passado de boca em boca para jamais ser esquecido. Daí a preocupação com o discurso crítico da História. Tudo isso ocorre no texto schmidtiano porque caminham juntas duas realidades: a textual e a extratextual. Assim como na biografia, na autobiografia, não há impedimento quanto à presença da ideologia de um historiador. Esta pode dividir a fronteira do discurso com a narrativa construída pelo autor e, outrossim, destacase a linha divisória entre o sujeito do enunciado e o sujeito da enunciação.

A evidência desse raciocínio, referente à obra literária aqui analisada, está em se comprovar que, tanto nas relações de identidade como de semelhança na elucidação dos conceitos entre os gêneros biografia, autobiografia e memória, só são oferecidas condições de se enxergar tais diferenças a partir de um modelo de hierarquização dessas relações. No atual estudo, o que interessa é o enfoque sobre a identidade enquanto critério para a caracterização do gênero autobiográfico, já que é o ponto de partida deste. Schmidt consegue conciliar uma prosa memorialística repleta de sombras da autobiografia. E qual a razão disso? Como se pode constatar? Se estamos admoestando as fronteiras dos subgêneros narrativos, dando mais ênfase a narrativas pessoais de cunho autodiegético, ou seja, o uso da $1^{a}$ pessoa do discurso para o registro das ações, a igualdade de quem narra e de quem participa dos fatos relatados implica identidade de fatos, como também semelhança; mas aí a semelhança do personagem da narrativa com o modelo. Significa dizer que mesmo numa história real, cujos acontecimentos são exclusivamente passados e tem-se o emprego da $1^{\text {a }}$ pessoa, o personagem é um sujeito do passado e da atualidade, pois o que é

https://periodicos.unifap.br/index.php/letras Macapá, v. 6, n. I, Io semestre, 2016. 
contado dele é como se ainda acontecesse. Há uma simultaneidade entre o passado e o presente. Chega-se, assim, a entender que em Schmidt a igualdade de funções entre o sujeito enunciador e o sujeito do enunciado se explica porque um está para outro e viceversa, assim como o autor está para esse modelo. O narrador schmitiano não é mais, segundo esse raciocínio teórico, coadjuvante de um passado em si, mas o coadjuvante de um presente em si no momento da enunciação. A Velha Firma, citado anteriormente, atesta o caráter linear dessas relações de identidade do lado autor e de semelhança do lado do modelo:

A entrada dos empregados da Casa Costa, Pereira \& Cia. era às sete e meia da manhã. Vinha eu, sempre de bonde, primeiro da Rua São Clemente, e, depois, de Copacabana, para onde se mudou minha família. Preferia o reboque; inexplicavelmente me parecia mais agradável. Viajava lendo. Podia-se ler nos bondes de outrora.

[...]

Chegava à Rua da Quitanda às sete e quinze. E esperava em pé, sempre lendo, em frente à Casa Costa, Pereira \& Cia. que abrissem as portas, e, em seguida, as cortinas de ferro. Abrir as portas, era verdadeira cerimônia. Quem possuía as chaves era o Seu Silva, um dos empregados mais antigos; o homem das cortinas era o Antônio, velho com mais de setenta anos, calvo e resmungão, mas bom sujeito. Nunca passara de carregador: pertencendo, assim, à classe de empregados que não usavam gravata.

Nessa mesma loja imensa, hoje irreconhecível, em reconstrução, entravam de cabeça baixa, tirando o chapéu respeitosamente, na porta da rua, os numerosos empregados da firma extinta. Entre eles, como um dos mais humildes componentes do grupo, estava eu próprio, com os meus livros. Esses livros causavam estranheza e mesmo certa irritação nos colegas, na sua maioria portugueses, trabalhadores, sérios, dedicados inteiramente à conquista do pão e da tranquilidade futura. (SCHMIDT, 1997, p. 67-68)

Quase que há o encontro, nessas memórias, entre os dois discursos, levemente corroborados - o do narrador e o do personagem. Verifica-se, nesse texto, o detalhamento na narração das horas de trabalho do narrador-autor, o ritual ao entrar na empresa, o cotidiano dos empregados, a repulsa de muitos quanto ao seu hábito de ler, a vida tranquila a caminho do serviço, 


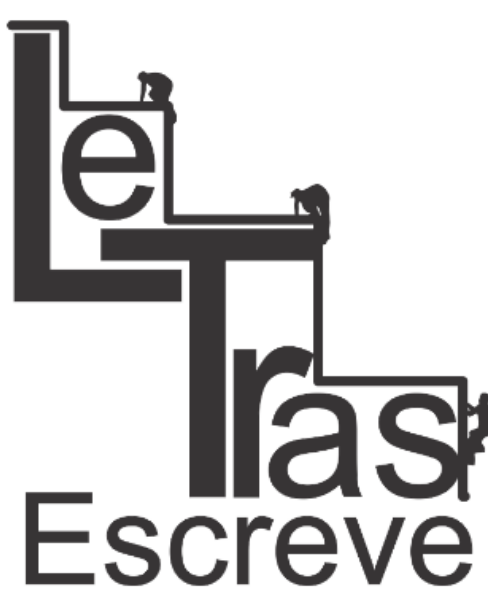

(ISSN 2238-8060) permissível de uma agradável leitura. São lembranças que fluem naturalmente e exigem do eu uma posição no sentido de registrá-las para que não se percam em meras reminiscências. Eis o comprometimento com os fatos reais e com a História, irmã esta da sabedoria a reeducar os homens a fim de também os redirecionar em suas andanças rumo ao futuro. "Muitas imagens, muitas histórias, muitas recordações continuaram a remoer-me, pedindo-me que as salvasse do esquecimento" (SCHMIDT, 1997, p. 68).

Até então, aparenta o escritor e também homem de negócios insistir no seu trabalho nessa linha da memorialística sempre que escreve prosa, orientando-nos a seguir com o nosso estudo por tal vertente de toda a teoria literária incipientemente discutida. Não custa nada agora direcionarmos a atenção à construção da memória individual do seu narrador, aqui, ademais, autor de um tempo histórico, marcado por intensas revoluções sociais e políticas. Toda a constituição da memória do eu nos escritos schmidtianos passa por um processo que envolve, primeiramente, uma meditação acerca dos estímulos neurológicos e psíquicos, sofridos pelo corpo humano. Este é receptor desses estímulos, que, depois, virarão imagens e, a partir daí, haverá uma interpretação do que elas representam para o espírito. Isto quer dizer que a relação entre o corpo e o espírito do sujeito o levará à retenção de circunstâncias do seu dia a dia, as quais, em conjunto, organizarão toda a sua memória ou registro de sua história individual ou coletiva, uma vez que as experiências do eu podem também explicar as da própria humanidade.

Os órgãos do sentido agem a ponto de que o sujeito trabalhe a sua percepção, ascendendo questões sobre a realidade e a idealidade do mundo exterior ao seu. Daí, as teorias da matéria e do espírito que vão lidar com o conceito de imagem, já que esta é o objeto-base para se entender a relação entre o lado material e o lado abstrato do ser humano. As imagens se processam de acordo com as leis da natureza. Umas influenciando as outras acabam 


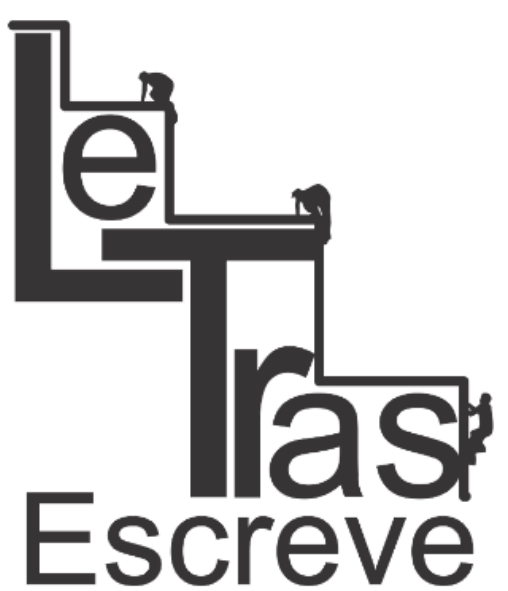

(ISSN 2238-8060) autorizando o cálculo científico que permitirá saber o que de certo se passa em cada uma delas. É preciso, enfim, conhecer os acontecimentos do tempo presente para poder se determinar o futuro de cada imagem e sempre uma irá prevalecer sobre as outras, porque serão analisadas não só mediante percepções, mas também afecções. Isto é: ter-se-á que investigá-las dentro e fora do corpo. Por isso, a indispensabilidade de tamanho elo; tudo passa pelo corpo para, de alguma maneira, o espírito extrair uma significação, e esta tornar-se uma lição para o sujeito. As afecções se processam conforme incitações do mundo exterior à pessoa e aplicam-se à realidade desta com base nos movimentos que vai executar. Quem as seleciona para a aplicação é a consciência, que garante a precisão das imagens. A afecção, portanto, pode, às vezes, ser utensílio da razão; outras vezes, até dispensá-la.

O corpo, então, seria um modelo de configuração de imagens particulares em que há movimentos centrífugos e, principalmente, centrípetos para que, pelo menos alguns destes, façam nascer um desenho do mundo exterior. Essa pulsação toda a acontecer no interior do sujeito a partir de seu contato com o que está fora dele persegue constantemente o eu schmidtiano. Em um escrito, intitulado Imagens do passado, de seu livro As florestas, o escritor, pela voz do narrador, explicita certas lembranças que trazem à tona experiências de sua vida amorosa, guardadas em sua memória e bastante representativas:

[...] Sua esquisitice resumia-se em deixar-se ver de longe, tal como Deus a fizera: nua.

Nós a olhávamos inquietos e pasmos todas as vezes, pois o espetáculo da sua nudez não se banalizava, não se tornava monótono, não perdia, pela repetição, nenhuma surpresa. Às oito horas da manhã, ela abria as persianas e se entregava aos nossos olhos ávidos; isso durava pouco mas vinha sempre certo. Era um presente extraordinário para os pobres seres que se reuniam nos dois quartos de frente daquela casa de pensão em São Paulo.

$[\ldots]$

Poucas namoradas tive e muitos sofrimentos. L. foi uma só vez ao cinema comigo. Assistimos juntos à Cleópatra, no antigo 


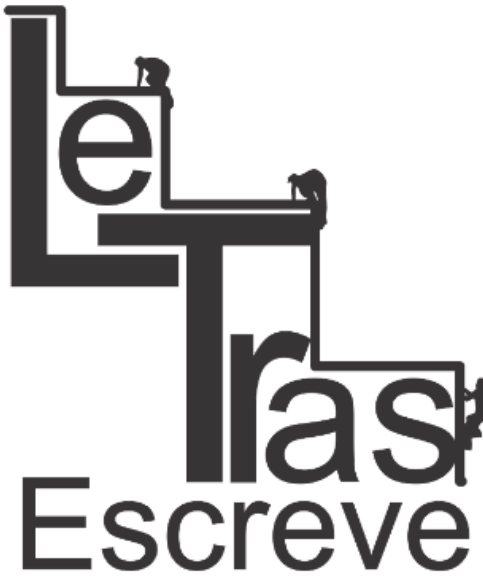

(ISSN 2238-8060)
Central, na Avenida Rio Branco, onde cantava, como atração, La Cumparsita.

$[\ldots]$

Ela ia dizendo essas coisas mas sua mão doce continuava prisioneira de minhas mãos. Era uma pessoa geniosa, de personalidade forte. Dessas que nasceram para mandar no marido. (SCHMIDT, 1997, p. 75-76)

Uma composição de imagens é traçada aí, e todas elas aparentemente desconexas, contudo, a temática do envolvimento íntimo prevalece em cada uma das situações apresentadas. Na que inicia a narrativa, ressaltando o valor da sexualidade juvenil; nas seguintes, o ensaio da conquista amorosa, antecedente da intimidade sexual. Bergson (2010) lança, em seu ensaio Matéria e memória, o desafio de se tentar excluir o mundo material, enquanto componente, desse processo de gênese da imagem no cérebro humano. Ao se propor a tal feito, correr-se-á o risco de um aniquilamento tanto da tarefa do próprio órgão gerenciador do sistema nervoso central quanto do estímulo, produzido pela imagem. Mas o estudioso também reconhece que não se pode condicionar o cérebro à criação imagética, posto que se isso acontecesse, quando muito as visões apagariam, mas a realidade, ou melhor, o universo que as compõe não deixaria de existir. Assim, os centros nervosos não podem condicionar a imagem do universo. Situações que estimulam a atividade nervosa a trabalhar a percepção qual artifício são as lembranças. Cada um dos capítulos da vida amorosa, desenhada na síntese anterior, se cruzam numa simbólica interface, como a sedimentarem todo o conteúdo abstrato, que será a memória. Esta abrigará as experiências do narrador Schmidt com base nas ações do personagem Schmidt. Porém, só poderão se reter aquelas em que o espírito encontra algum significado ou representação, conforme se pode recapitular. Não é à toa que se pressente a escrita fragmentária como resultado da seleção de quais imagens serão guardadas pela mente para, depois, servirem de exemplo a quem enfrentar semelhantes circunstâncias e com elas identificar-se enquanto sujeito. De certa maneira, o que pode passar

https://periodicos.unifap.br/index.php/letras Macapá, v. 6, n. I, Io semestre, 2016. 
despercebido é restituído ao palco da História, buscando-se algum entendimento e conscientização. Em Imagens perdidas, também do livro As florestas, tem-se a prova de um eu que luta para que a memória seja preenchida de seu enorme vazio por novas lembranças, mesmo que apresentadas rapidamente pelo mundo do autor:

Com os cabelos em desalinho, M.C. atravessou a sala de jantar. Trazia uma toalha nos ombros. Acabara de despertar e seus olhos ainda recebiam mal a luz do meio-dia. [...]

Essa imagem de M.C., descuidada e natural, é de todas as que dela possuo a que jamais desaparecerá de minha lembrança. Sempre a verei assim, graciosa, espontânea, bela na sua juventude, tal como o foi há bem mais de trinta anos, quando eu jurava a Deus e a mim mesmo que haveria de amá-la para sempre... (SCHMIDT, 1997, p. 155)

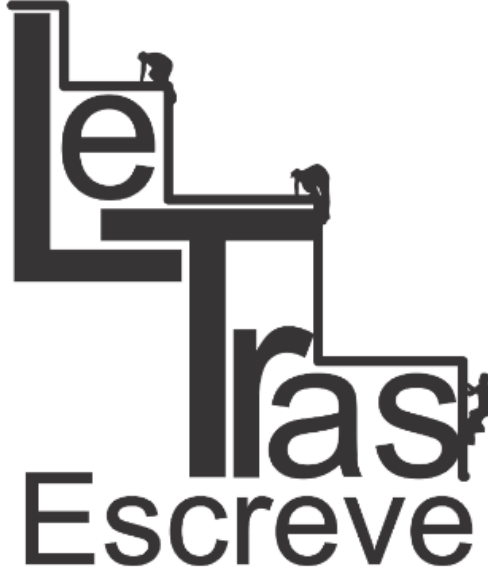

(ISSN 2238-8060)

O que está sendo dito condiz, mais uma vez, com o papel do corpo em toda a construção imagética. As imagens que cercam o nosso corpo físico sofrem modificações, causadas por ele, e estabelece-se uma relação de troca: uma imagem confere ao corpo movimento, e esse influi sobre ela, restituindo-a o próprio movimento, como também às demais, ligadas a ela. Depois desse ciclo, pode-se deduzir uma única diferença - a de que o corpo, pelo menos, nesse balanço cíclico, seleciona o que acha merecedor de uma devolução à exterioridade. Fica a discussão: o corpo humano seria matéria ou imagem? Dependendo do referencial, se for considerado pura matéria, integra o mundo material, existindo ao seu redor; se imagem, só poderá absorver o que ela oferecer, isto é, sendo ela uma simples imagem no corpo, remove parte dela e não o todo, este presente no universo, representante do real. O corpo, então, é um centro de ação que, sozinho, jamais poderia produzir uma representação. Mais ou menos, é o que se tem nesse trecho da narrativa de Augusto Frederico Schmidt, no qual uma percepção de fatos atuais despertou, através da lembrança, conjunturas sociais bastante representativas e, assim, passaram a agregar a memória individual do narrador-autor. Dentre elas, as que têm como 


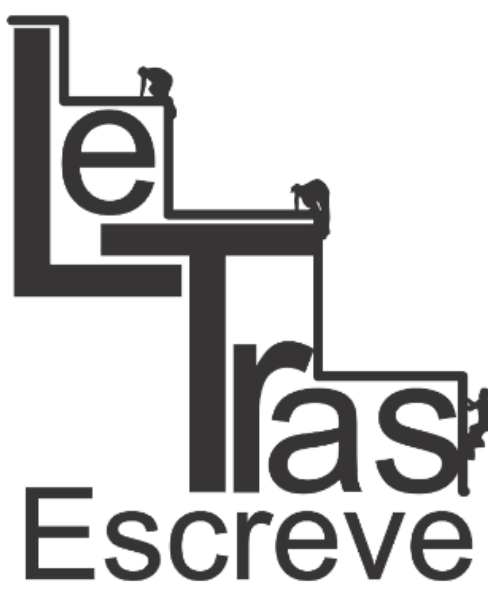

(ISSN 2238-8060) personagens as mais reais ou ilusórias figuras femininas, importantes para a instalação da afetividade, que irá permear toda a vida do autor de Navio perdido, instruindo-lhe quanto aos seus sonhos de desfrutar de um futuro ao lado do grande amor, da doce amada, da eternidade. A respeito, vamos encontrar em sua biografia esse desejo tão oculto, mas que está, ao mesmo tempo, tão visível em sua obra em poesia e prosa. Por não ter tido sucesso nos estudos e ter terminado como comerciário, empregado num armarinho, por achar-se obeso e não atraente às mulheres, a frustração de toda uma existência feliz, de quando em quando, o perseguia em seus escritos. Um episódio de sua biografia romanceada, Quem contará as pequenas histórias?, escrita por Mey e Alvim (2005, p. 54) comprova o dito, enfocando o dia em que o escritor fora dispensado do serviço após uma injustiça sofrida pelo chefe do estabelecimento comercial e fora, inutilmente, buscar consolo nos braços de uma futura moça por quem se enamorara: "Nem mesmo uma namorada conseguiria arranjar! Perdera mais essa oportunidade. O dia anterior determinara seu destino para sempre. Parecia fadado ao fracasso na vida e no amor".

Todos os constituintes que nos levam a crer na corrente autor-narrador-personagem, explicada antes, passam, primeiramente, pelo túnel da memória. Esta inicia seu trajeto pelo próprio sujeito para, em seguida, ganhar às ruas, às avenidas, às comunidades, assumindo de vez o seu posto social. A noção de coletividade é que subsidia os alicerces do registro sócio-histórico, fazendo do sujeito do mesmo modo que um ser particular, um ser histórico. Temos dois discursos a se amalgamarem a ponto de derivarem controvérsias sobre a autenticidade dos relatos; quem estaria com a verdade? A realidade seria retratada tal qual o sujeito a vê? Quais seriam as fronteiras entre a Arte e a Ciência Histórica? Em que aspectos uma poderia complementar o que a outra afiança? Ponderar essas interrogações guiaria nossas ações em prol de uma causa ao longo desta produção científica: demonstrar que a

https://periodicos.unifap.br/index.php/letras Macapá, v. 6, n. I, Io semestre, 2016. 
literatura também é um discurso engajado e é capaz de transformar uma realidade, porque a recria sob um prisma de quem a produz. Ao mexer com os anseios do sujeito, bem como com suas emoções, particulariza, dando voz a todos, confrontando pontos de vista, que, muitas vezes, um eu histórico se vê na obrigação de calar em respeito ao forte tecnicismo do método científico que a sua respectiva área de atuação impõe à pesquisa.

\section{Referências bibliográficas}

BERGSON, Henri. Matéria e memória: ensaio sobre a relação do corpo com o espírito. Trad. Paulo Neves. 4.ed. São Paulo: WMF Martins Fontes, 2010.

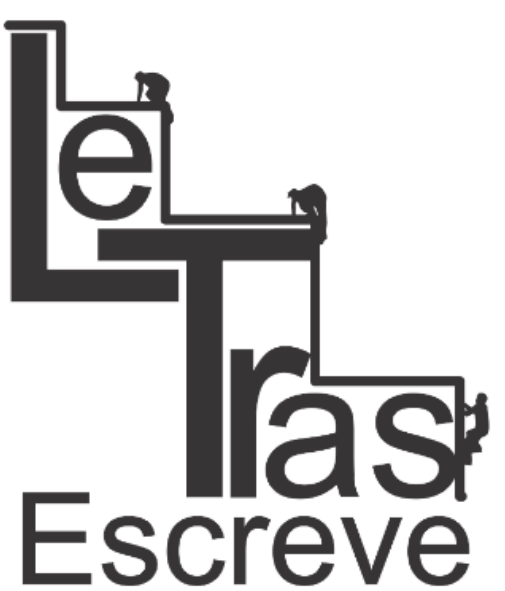

(ISSN 2238-8060)

LEJEUNE, Philippe. O pacto autobiográfico: De Rousseau à Internet. Trad. Jovita Maria Gerheim Noronha e Maria Inês Coimbra Guedes. Belo Horizonte: Ed. UFMG, 2008. 404p.

MEY, Letícia; ALVIM, Euda. Quem contará as pequenas histórias: uma biografia romanceada de Augusto Frederico Schmidt. São Paulo: Globo, 2005.

SCHMIDT, Augusto Frederico. As florestas - páginas de memórias. 2.ed. Rio de Janeiro: Topbooks, 1997. 273p.

Saudades de mim mesmo: uma antologia de prosa de Augusto Frederico Schmidt. ALVIM, Euda; MEY, Letícia (orgs.). São Paulo: Globo, 2006.

Recebido em 15/05/2016. Aprovado em 18/06/2016. 